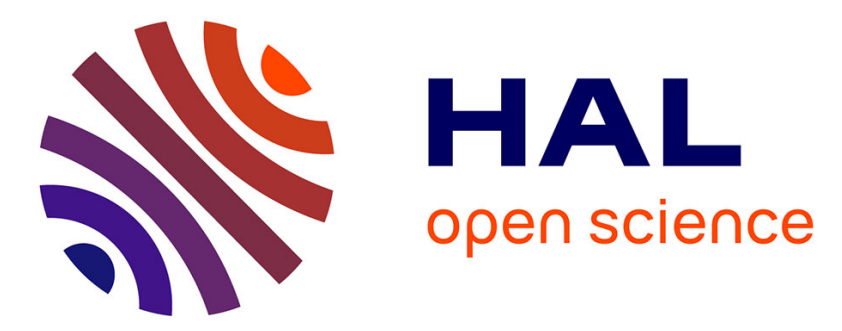

\title{
Bicarbonate Supplement Restores Urinary Klotho Excretion in Chronic Kidney Disease: A Pilot Study
}

\author{
V. Hage, C. Villain, S. Pelletier, M. Laville, J. Drai, D. Fouque
}

\section{To cite this version:}

V. Hage, C. Villain, S. Pelletier, M. Laville, J. Drai, et al.. Bicarbonate Supplement Restores Urinary Klotho Excretion in Chronic Kidney Disease: A Pilot Study. J Ren Nutr, 2019, 29 (4), pp.285-288. 10.1053/j.jrn.2018.11.001 . hal-02195243

\section{HAL Id: hal-02195243 \\ https://hal.science/hal-02195243}

Submitted on 25 Oct 2021

HAL is a multi-disciplinary open access archive for the deposit and dissemination of scientific research documents, whether they are published or not. The documents may come from teaching and research institutions in France or abroad, or from public or private research centers.
L'archive ouverte pluridisciplinaire HAL, est destinée au dépôt et à la diffusion de documents scientifiques de niveau recherche, publiés ou non, émanant des établissements d'enseignement et de recherche français ou étrangers, des laboratoires publics ou privés.

\section{다)(1) $(5$}

Distributed under a Creative Commons Attribution - NonCommerciall 4.0 International 


\title{
Bicarbonate Supplement Restores Urinary Klotho Excretion in Chronic Kidney Disease: A Pilot Study
}

\author{
Valerie Hage, MD, * Cedric Villain, MD, † Solenne Pelletier, MD, PhD, $\neq$ Maurice Laville, MD,* \\ Jocelyne Drai, PharmD, S and Denis Fouque, MD, PhD*
}

Objective: We tested the hypothesis that correcting acidosis may improve urinary Klotho excretion and serum $\alpha$-Klotho.

Design: This is a prospective, interventional, nonrandomized, open-label trial study. In this study setting, metabolic acidosis is commonly observed during chronic kidney disease (CKD). We reported a positive relationship between serum bicarbonate (Sbicar) and serum $\alpha$-Klotho in these patients.

Subjects: The study involved 20 patients with a known kidney disease referred for renal checkup. Inclusion criteria were age $\geq 18$ years, CKD stage 3-5 non dialysis, Sbicar $<22 \mathrm{mmol} / \mathrm{L}$, and not receiving bicarbonate supplementation.

Intervention: Patients were then prescribed $1 \mathrm{~g}$ of oral sodium bicarbonate 3 times per day for 4 weeks.

Main outcome measure: Patients were evaluated at two and 4 weeks by blood and urine measurements.

Results: Mean serum Klotho was $615 \pm 287 \mathrm{pg} / \mathrm{mL}$, and mean serum Sbicar was $19.3 \pm 1.7 \mathrm{mmol} / \mathrm{L}$ at baseline. Sbicar increased from baseline at two $(23.9 \pm 2.9 \mathrm{mmol} / \mathrm{L}, P<.001)$ and 4 weeks $(23.4 \pm 1.9 \mathrm{mmol} / \mathrm{L}, P<.001)$. There was no change in serum $\mathrm{Klotho}$ at two $(630 \pm 333 \mathrm{mmol} / \mathrm{L})$ and 4 weeks $(632 \pm 285 \mathrm{mmol} / \mathrm{L})$. By contrast, urine Klotho/creatinine ratio, which was very low at baseline (34.6 $\pm 31.6 \mathrm{pg} / \mathrm{mmoL})$, increased by $320 \%$ at two weeks $(P<.005)$ and by $280 \%$ at 4 weeks $(P<.01)$.

Conclusions: Correcting acidosis by oral administration of sodium bicarbonate rapidly increases the urine excretion of soluble $\alpha$-Klotho in CKD patients. However, a 4-week bicarbonate treatment was not able to increase serum $\alpha$-Klotho. A longer study may confirm this pilot observation and increase serum Klotho, which has been shown to exert a protective cardiovascular effect during CKD.

(c) 2018 by the National Kidney Foundation, Inc. All rights reserved.

\section{Introduction}

$\mathrm{K}^{1}$ LOTHO WAS IDENTIFIED in 1997 as an "agingsuppressor" gene in mice. It accelerates aging when disrupted and extends life span when overexpressed. Klotho encodes a single-pass transmembrane protein and is predominantly expressed in renal tubules. ${ }^{1}$ Klotho is almost exclusively produced by the kidney, ${ }^{2}$ and chronic kidney disease (CKD) is associated with $\alpha$-Klotho deficiency in serum and urine, even in the early stage of the disease. ${ }^{3-6}$ The regulation of Klotho synthesis is largely unknown, although metabolic acidosis and proteinuria have been recently identified as covariates of circulating Klotho.

\footnotetext{
${ }^{\star}$ Univ Lyon, UCBL, CARMEN, CENS, Département de NéphrologieDialyse-Nutrition, Centre Hospitalier Lyon-Sud, Pierre Bénite, France.

${ }^{\dagger}$ Univ Lyon, UCBL, CNRS LBBE, Département de Néphrologie-DialyseNutrition, Centre Hospitalier Lyon-Sud, Pierre Bénite, France.

${ }^{\ddagger}$ Univ Lyon, UCBL, Inserm 1033, Département de Néphrologie-DialyseNutrition, Centre Hospitalier Lyon-Sud, Pierre Bénite, France.

${ }^{\$}$ Univ Lyon, UCBL, Laboratoire de Biochimie, CARMEN, CENS, Centre Hospitalier Lyon-Sud, Pierre Bénite, France.

Financial Disclosure: The authors have no conflict of interest to disclose.

Address correspondence to Denis Fouque, MD, PhD, Renal department, Centre hospitalier Lyon Sud, Chemin du grand revoyet, 69495 Pierre-Bénite, France.E-mail: denis.fouque@chu-lyon.fr

(c) 2018 by the National Kidney Foundation, Inc. All rights reserved.

$1051-2276 / \$ 36.00$

https://doi.org/10.1053/j.jrn.2018.11.001
}

We therefore tested the hypothesis that correcting acidosis may improve serum $\alpha$-Klotho and urinary Klotho excretion.

\section{Patients}

\section{Subjects and Methods}

The study involved 20 patients with a known kidney disease referred on a planned appointment for a renal checkup. The study was presented to all patients, and an informed consent was obtained from each participant. The study was accepted by the Ethical Committee of Hospices Civils de Lyon. Treatment with oral bicarbonate was performed on a routine basis, as recommended by international guidelines and proposed to all acidemic patients in our unit. $\mathrm{Pa}-$ tients met the following inclusion criteria: age $\geq 18$ year, CKD stage 3-5 ND according to CKD-EPI formula, ${ }^{9} \mathrm{Sbi}-$ $\mathrm{car}<22 \mathrm{mmol} / \mathrm{L}$, and not receiving a bicarbonate supplementation. Patients were excluded if they had acute illness, urinary diversion, digestive system fistula, chronic diarrhea, chronic obstructive pulmonary disease, history of active cancer, proteinuria $>3 \mathrm{~g} /$ day, and obesity defined as a body mass index $\geq 30 \mathrm{~kg} / \mathrm{m}^{2}$.

\section{Blood Measurements}

Blood was drawn at 7:45 AM before breakfast and after an overnight fast. Samples were immediately chilled on 
ice and centrifuged at 3,000 g, and then serum or plasma was separated and samples were kept at $-80^{\circ} \mathrm{C}$ until measurements. The following biological data were measured by standard laboratory methods: (1) serum calcium, (2) phosphorus, (3) bicarbonate, (4) potassium, (5) magnesium, (6) urea, (7) creatinine (Cr), (8) C-reactive protein, (9) albumin, and (10) hemoglobin. Intact parathyroid hormone was measured with a third-generation chemiluminescent assay (Liaison $®$; DiaSorin, Saluggia, Italy; range of normal values: $5.5-38.4 \mathrm{ng} / \mathrm{L}), 25-\mathrm{OH}$ vitamin $\mathrm{D}$ was measured with chemiluminescent immunoassay (Liaison ${ }^{\circledR}$; DiaSorin, Saluggia, Italy; range of desirable values: 30-80 ng/ $\mathrm{mL}$ ), serum $\alpha$-Klotho was measured by quantitative sandwich enzyme-linked immunosorbent assay (ELISA) (IBL, Japan; range of normal values: 239-1266 pg/mL), and serum C-terminal fibroblast growth factor (FGF23) was measured by quantitative sandwich ELISA (Immutopics, San Clemente, CA; range of normal values: 34-96 Ru/ $\mathrm{mL}$ ). Serum bicarbonate was immediately measured after sampling.

\section{Urinary Measurements}

Urine samples were obtained in the morning, when blood samples were collected. Klotho was measured by quantitative sandwich ELISA (IBL, Japan; range of normal values: $239-1266 \mathrm{pg} / \mathrm{mL}$ ). Because we did not collect $24-$ hour urine, we reported the ratio of solutes over $\mathrm{Cr}$ to normalize for daily urine output.

\section{Treatment}

After initial baseline measurements, patients were asked to take the routine supplement of $1 \mathrm{~g}$ of sodium bicarbonate orally 3 times per day. They were evaluated at two and 4 weeks thereafter by blood and urine measurements. As the study was pilot in nature, no control group was used.

\section{Statistics}

Data are expressed as mean \pm standard deviation or median \pm interquartile range when required. Statistical differences between biological values at baseline and during bicarbonate supplementation were assessed by repeated measures analysis of variance. A $P$-value less than 0.05 was considered as statistically significant. All statistical analyses were performed using the $\mathrm{R}$ software (version 3.0.2; libraries lme 4, nlme, plotrix, and lattice).

\section{Results \\ Patients' Characteristics}

We included 20 patients ( $57 \%$ women) of a median age of 68.0 (58.5-77.8) years. The main clinical and anthropometric characteristics of the study population are summarized in Table 1.

\section{Variations from Baseline}

Mean serum Klotho was $615 \pm 287 \mathrm{pg} / \mathrm{mL}$, and the mean serum Sbicar was $19.3 \pm 1.7 \mathrm{mmol} / \mathrm{L}$ at baseline, confirming a mild degree of metabolic acid disorder. Sbicar
Table 1. Patients' Characteristics and Serum and Urine Values at Baseline

\begin{tabular}{lc}
\hline Variable & Value \\
\hline Age $(\mathrm{y})$ & $68(58.5-77.8)$ \\
Gender $(\%$ women) & 57.1 \\
Body mass index $\left(\mathrm{kg} / \mathrm{m}^{2}\right)$ & $26.3 \pm 4.7$ \\
Serum & \\
$\alpha-\mathrm{Klotho}(\mathrm{pg} / \mathrm{mL})$ & $614.6 \pm 287.2$ \\
FGF $23(\mathrm{RU} / \mathrm{mL})$ & $469.9 \pm 628.1$ \\
25-OH vitamin D $(\mathrm{nmol} / \mathrm{L})$ & $51.0 \pm 24.9$ \\
Intact parathyroid hormone $(\mathrm{pg} / \mathrm{mL})$ & $92.6 \pm 97.4$ \\
C-reactive protein $(\mathrm{mg} / \mathrm{L})$ & $6.0 \pm 5.7$ \\
Albumin $(\mathrm{g} / \mathrm{L})$ & $38.8 \pm 3.7$ \\
Bicarbonate $(\mathrm{mmol} / \mathrm{L})$ & $19.3 \pm 1.7$ \\
Calcium $(\mathrm{mmol} / \mathrm{L})$ & $2.3 \pm 0.1$ \\
Phosphorus $(\mathrm{mmol} / \mathrm{L})$ & $1.2 \pm 0.4$ \\
Creatinine $(\mu \mathrm{mol} / \mathrm{L})$ & $148.0(132.5-194.5)$ \\
eGFR $\left(\mathrm{CKD}-\mathrm{EPI}, \mathrm{mL} / \mathrm{min} / 1.73 \mathrm{~m}{ }^{2}\right)$ & $35.0(23.5-43.3)$ \\
Hemoglobin $(\mathrm{g} / \mathrm{L})$ & $116.6 \pm 18.3$ \\
Urine & \\
Proteinuria $(\mathrm{g} / \mathrm{d})$ & $1.2 \pm 1.4$ \\
Urine pH & $6.4 \pm 0.8$ \\
Urine Klotho/creatinine $(\mathrm{pg} / \mathrm{mmol})$ & $34.6 \pm 31.6$ \\
\hline
\end{tabular}

CKD-EPI, chronic kidney disease-epidemiology; FGF, fibroblast growth factor.

Values for categorical variables are given as number; values for continuous variables are given as mean \pm standard deviation, and those for noncontinuous variables were given as median and interquartile range.

increased by approximately $25 \%$ from baseline at two $(23.9 \pm 2.9 \mathrm{mmol} / \mathrm{L}, \quad P<.001)$ and 4 weeks $(23.4 \pm 1.9 \mathrm{mmol} / \mathrm{L}, P<.001)$. Serum Klotho slightly increased at two $(630 \pm 333)$ and 4 weeks $(632 \pm 285)$; however, this was not significant. By contrast, urine Klotho/Cr ratio, which was very low at baseline $(34.6 \pm 31.6 \mathrm{pg} / \mathrm{mmoL})$, increased by $320 \%$ at two weeks $(P<.005)$ and by $280 \%$ at 4 weeks $(P<.01)$ (Figure 1$)$. Urinary $\mathrm{pH}$ did not significantly change from $6.38 \pm 0.78$ to $6.67 \pm 0.70$ at two weeks $(P=.13)$ and to $6.42 \pm 0.89$ at 4 weeks $(P=.93)$.

Variations of Urinary Klotho/Creatinine Ratio during the study (mean +/- SEM)

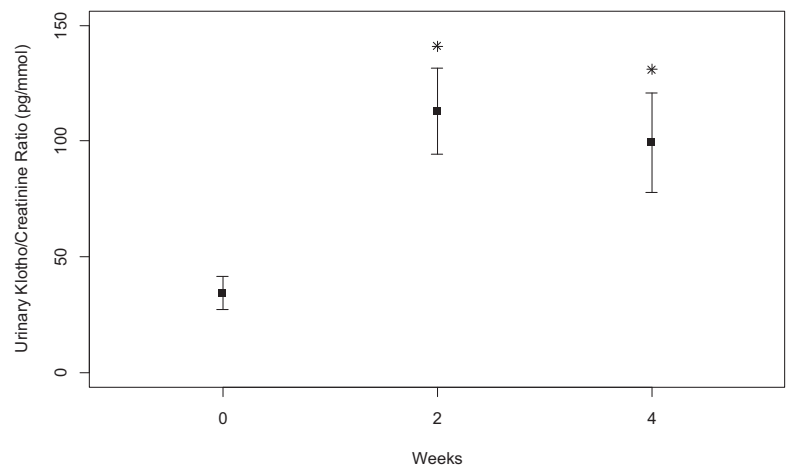

Figure 1. Variations of urinary Klotho/creatinine ratio during bicarbonate treatment $\left(n=20\right.$; ${ }^{*}$ indicates $\left.P<.05\right)$. 
Table 2. Serum Values Before and Two and Four Weeks After Bicarbonate Supplementation ( $n=20$, ANOVA Test From Baseline Values)

\begin{tabular}{lccccc}
\hline Mean $\pm \mathrm{SD}$ & Baseline & Week 2 & $P$ & Week 4 \\
\hline Klotho $(\mathrm{pg} / \mathrm{mL})$ & $614.6 \pm 287.2$ & $630.2 \pm 333.5$ & .35 & $632.1 \pm 284.9$ & .78 \\
Bicarbonate $(\mathrm{mmol} / \mathrm{L})$ & $19.3 \pm 1.7$ & $23.9 \pm 2.9$ & $<.001$ & $23.4 \pm 1.9$ & $<.001$ \\
\hline
\end{tabular}

ANOVA, analysis of variance; SD, standard deviation.

\section{Discussion}

This pilot study shows that it is possible to increase the reduced urinary Klotho excretion during stages 3-5 ND CKD by correcting metabolic acidosis. Indeed, we found for the first time that correcting acidosis is associated with higher urine Klotho/Cr ratio at week two and four after an oral alkaline therapy. The concentration of $\alpha$-Klotho in human urine is estimated to be $20-200 \mathrm{pM} .^{10}$ The measurement of the protein-to-Cr ratio in a single random urine specimen has been focused on as an approach that can be used to avoid the need for a 24-hour urine collection. ${ }^{11,12}$ The random urine Klotho/Cr ratio, as well as the amount of 24-hour urinary Klotho, correlated inversely with the stages of $\mathrm{CKD}^{6}$ and is reported to be a surrogate marker of functioning nephrons in patients with CKD. ${ }^{6,13}$ The measurement of Klotho in urine may have been sensitive to $\mathrm{pH}$, and this might have introduced a bias in our study. However, there was no significant difference in urinary $\mathrm{pH}$ between the different study phases, which reduces this potential caveat.

Several retrospective studies showed a clear association between acid-base imbalance and increased mortality. ${ }^{14,15}$ Recently, a large randomized study providing sodium bicarbonate supplementation slowed the rate of decline of renal function as assessed by $\mathrm{CrCl}$ to $1 \mathrm{~mL} /$ minute/year as compared with $2.5 \mathrm{~mL} /$ minute/year in untreated patients. It also significantly reduced the number of patients who progressed to end-stage renal disease. ${ }^{16,17}$ The fact that serum $\alpha$-Klotho is reduced during chronic acidosis might be paralleled with the increased mortality described in CKD patients' clinical reports. In addition, in a recent prospective cohort of 235 patients undergoing hemodialysis, those in the upper quartile of serum Klotho had a $14 \%$ lower cardiovascular morbidity and mortality. ${ }^{18}$

We previously showed a positive relationship between serum bicarbonate and serum levels of $\alpha$-Klotho. ${ }^{7}$ The Klotho gene is expressed predominantly in the distal convoluted tubule in the kidney and choroid plexus in the brain. ${ }^{1}$ Soluble Klotho can be generated by two possible mechanisms: cell membrane shedding by proteases such as ADAM10 or $17^{19}$ or by alternative splicing into blood or urine. ${ }^{20}$ It has been recently found that $\alpha$-Klotho travels across renal tubules from basolateral to intracellular location and is then secreted across the apical membrane into the urinary lumen. ${ }^{21}$ Moreover, Sakan et al. ${ }^{22}$ found that renal dysfunction initially induces a reduction in renal $\alpha$-Klotho expression, which in turn reduces circulating serum Klotho levels, suggesting that the serum Klotho concentration may be a useful marker of the renal $\alpha$-Klotho level.

We can speculate that the tubular function changes that occur in response to metabolic acidosis may be implicated in the altered expression of serum and urine $\alpha$-Klotho at the secretory site of the tubules. Correcting acidosis may restore $\alpha$-Klotho production or its cleavage process to first appear in urine then in serum. This hypothesis should be confirmed in further research. The fact that we did not observe a rise in serum Klotho may not be unexpected because our study was pilot and of short duration, and there might be a transitory phase before serum Klotho starts to rise. This hypothesis could be easily verified by expanding the study duration. Of note, there was a good compliance of oral bicarbonate treatment without patient complaints and an efficient increase in serum bicarbonate as soon as 2 weeks after starting the supplement (Table 2).

In conclusion, the previous observation of a positive relationship between serum $\alpha$-Klotho and serum bicarbonate $^{7}$ and the current report of an oral bicarbonate supplement being able to increase urinary Klotho excretion give credit to a potential link between acidosis control and kidney protection. Given the fact that Klotho exerts prominent cell protection and antiaging effects, Klotho deficiency during CKD, particularly during end-stage renal disease, should be undeniably prevented. Acidosis correction may represent a simple potential target to improve this defect.

\section{Practical Application}

Correcting acidosis by oral administration of sodium bicarbonate rapidly increases the urine excretion of soluble $\alpha$-Klotho in CKD patients.

\section{Acknowledgments}

The authors are deeply indebted to the outpatient clinic nurses and staff and particularly to Pierre Trolliet, MD, Abbas Deeb, MD, and Mathilde Nouvier, MD. The authors also thank Hospices Civils de Lyon for research support.

\section{References}

1. Kuro-O, M. Klotho and endocrine fibroblast growth factors: marker of chronic kidney disease progression and cardiovascular complications? https:// www.ncbi.nlm.nih.gov/pubmed/29800324. Accessed December 17, 2018.

2. Lindberg K, Amin R, Moe OW, et al. The kidney is the Principal Organ Mediating klotho effects. J Am Soc Nephrol. 2014;25:2169-2175. 
3. Barker SL, Pastor J, Carranza D, et al. The demonstration of $\alpha$ Klotho deficiency in human chronic kidney disease with a novel synthetic antibody. Nephrol Dial Transplant. 2015:223-233.

4. Fernandez-Fernandez B, Izquierdo MC, Valiño-Rivas L, et al. Albumin downregulates Klotho in tubular cells. Nephrol Dial Transplant. 2018;33:17121722 .

5. Kim HR, Nam BY, Kim DW, et al. Circulating $\alpha$-klotho levels in CKD and relationship to progression. Am J Kidney Dis. 2013;61:899-909.

6. Akiomoto T, Yoshizawa H, Watanabe Y, et al. Characteristics of urinary and serum soluble Klotho protein in patients with different degrees of chronic kidney disease. BMC Nephrol. 2012;13:155.

7. Hage V, Pelletier S, Dubourg L, et al. In chronic kidney disease, serum $\alpha$-Klotho is related to serum bicarbonate and proteinuria. J Ren Nutr. 2014;24:390-394.

8. de Seigneux S, Courbebaisse M, Rutkowski JM, et al., for the NephroTest Study Group. Proteinuria increases plasma phosphate by altering its tubular Handling. J Am Soc Nephrol. 2015;26:1608-1618.

9. Levey AS, Stevens LA, Schmid CH, et al. For the CKD-EPI (chronic kidney disease Epidemiology Collaboration): a New Equation to estimate Glomerular Filtration rate. Ann Intern Med. 2009;150:604-613.

10. Cha SK, Ortega B, Kurosu H, Rosenblatt KP, Kuro -OM. Removal of sialic acid involving Klotho causes cell-surface retention of TRPV5 channel via binding to galectin-1. Proc Natl Acad Sci U S A. 2008;105:9805-9810.

11. Ginsberg JM, Chang BS, Matarese RA, Garella S. Use of single voided urine samples to estimate quantitative proteinuria. $N$ Engl $J$ Med. 1983;309:1543-1546.

12. Guy M, Borzomato JK, Newall RG, Kalra PA, Price CP. Protein and albumin-to-creatinine ratios in random urines accurately predict $24 \mathrm{~h}$ protein and albumin loss in patients with kidney disease. Ann Clin Biochem. 2009;46:468-476.
13. Hu MC, Shi M, Zhang J, Quinones H, Griffith C. Klotho deficiency causes vascular calcification in chronic kidney disease. J Am Soc Nephrol. 2011;22:124-136.

14. Kovesdy CP, Anderson JE, Kalantar-Zadeh K. Association of serum bicarbonate levels with mortality in patients with non-dialysis-dependent CKD Nephrol Dial Transpl. 2009;24:1232-1237.

15. Shah SN, Abramowitz M, Hostetter TH, Melamed ML. Serum bicarbonate levels and the progression of kidney disease: a cohort study. Am J Kidney Dis. 2009;54:270-277.

16. de Brito-Ashurst I, Varagunam M, Raftery MJ, Yaqoob MM. Bicarbonate supplementation Slows progression of CKD and improves Nutritional Status. J Am Soc Nephrol. 2009;20:2075-2084.

17. Kalantar-Zadeh K, Fouque D. Nutritional Management of Chronic Kidney Disease. N Engl J Med. 2017;377:1765-1776.

18. Marcais C, Maucort-Boulch D, Drai J, et al. Circulating klotho Associates with cardiovascular morbidity and mortality during hemodialysis. J Clin Endoc Metab. 2017;102:3154-3162.

19. Chen CD, Podvin S, Gillespie E, Leeman SE, Abraham CR. Insulin stimulates the cleavage and release of the extracellular domain of Klotho by ADAM10 and ADAM17. Proc Natl Acad Sci USA. 2007;104:19796-19801.

20. Matsumura Y, Aizawa H, Shiraki-Iida T, Nagai R, Kuro-o M, Nabeshima Y. Identification of the human klotho gene and its two transcripts encoding membrane and secreted klotho protein. Biochembiophys Res Commun. 1998;242:626-630.

21. Hu MC, Shi M, Zhang J, et al. Renal production, Uptake, and Handling of circulating $\alpha$ Klotho. J Am Soc Nephrol. 2016;27:79-90.

22. Sakan H, Nakatani K, Asai1 O, et al. Reduced renal a-klotho expression in CKD patients and its effect on renal phosphate Handling and vitamin D metabolism 2014. PLoS One. 2014;9. 